\title{
Support Vector Regression Implementation for Indonesian Private External Debt Analysis
}

\author{
Zuherman Rustam and Janice Diani
}

\begin{abstract}
Indonesian corporations have been borrowing large sums of money from foreign investors in the past decade, such that private debt ratio has reached $49 \%$ of Indonesia's total external debt by the end of 2017. This act of borrowing might improve the borrowing firms' performance which leads to increase in profit, but in other hand it might result on debt value expansion, due to the exchange rate depreciation trend in Indonesia. This paper employs Support Vector Regression, a machine-learning method, to study the relationship between factors that might affect corporate performance, and compares the results with that of the conventional panel data regression method. The study was done using data from annual financial statements of 189 firms in Indonesia during 2011-2017.

It is shown that the machine-learning approach discussed in this study gave better accuracy than the previously employed panel data regression method. Both methods generally showed that balance-sheet effect is more dominant in Indonesian corporations, and it is recommended for companies to minimize their foreign debts and imported purchases, and if possible, export more of their products.
\end{abstract}

Index Terms - depreciation; exchange rate; external debt; machine learning; support vector regression.

\section{INTRODUCTION}

Indonesia's external debt has been rising in the past decade, with $10.03 \%$ year on year growth rate. At first the debt was dominated by public debt, but the private debt ratio started increasing in 2012, and it has reached $49 \%$ of the total external debt by the end of 2017. [1]

The large amount of private debt, in one hand, might improve the borrowing companies' performance and increase their profit. This is caused by two main causes: firstly, it is expected from a company to produce more when it has more capital [2]. Secondly, according to the MundellFleming model, the depreciation trend increases the company's competitiveness towards foreign competitors, especially for exporter companies. This is known as competitiveness effect [3].

On the other side, it also might expose said corporations to the latent risk of depreciation. The nominal value of external debt would inflate when depreciation happens. This is known as balance-sheet effect [4]. When depreciation occurs and the amount of debt expands, there is risk that the borrowing company might not be able to repay said debt. This phenomenon is called currency mismatch, and it is very dangerous since it might cause bankruptcy to the company, and even economic contraction and major unemployment when it happens to a big number of companies at the same time [2].
Therefore, this study intends to investigate the relationship between external debt and other factors that affects corporate performance, so that the currency mismatch could be avoided and the best policy that maximizes the company's profit could be made.

This study had been done by the Central Bank of Indonesia using multivariate statistics method, namely panel data regression [2]. The result didn't give satisfactory accuracy since the data was a combination of time series and cross-section data. In this paper, we would like to do an experiment using Support Vector Regression (SVR), which is a machine learning method. SVR is known for its ability to give good predictions in some regression cases $[5,6,7]$.

\section{METHODOLOGY}

The Central Bank of Indonesia derived the factors that affect a firm's performance from their balance sheet. A firm's performance is evaluated by its equity to asset ratio [2].

At time 0, a company's balance sheet could be defined as

$$
A=L+W_{0}
$$

where A represents asset, $\mathrm{L}$ represents liabilities, and $\mathrm{W}$ represents firm's equity (net worth). Firm's asset and liabilities might be in domestic or foreign currencies, where $A=A_{d}+e_{0} A_{f}$ and $L=L_{d}+e_{0} L_{f}$, such that Equation (1) could be written as

$$
A_{d}+e_{0} A_{f}=L_{d}+e_{0} L_{f}+W_{0}
$$

where

$A_{d}=$ asset in domestic currency (Rupiah)

$A_{f}=$ asset in foreign currencies

$L_{d}=$ liabilities in domestic currency (Rupiah)

$L_{f}=$ liabilities in foreign currencies

$e_{0}=$ exchange rate (to USD)

Therefore, in time 1, the previous equation could be written as

$$
\begin{aligned}
\left(1+r_{d}^{A}\right) A_{d}+(1 & \left.+r_{f}^{A}\right) \cdot e_{1} A_{f} \\
& =\left(1+r_{d}^{L}\right) L_{d}+\left(1+r_{f}^{L}\right) \cdot e_{1} L_{f} \\
& +W_{1} \\
W_{1}=\left(1+r_{d}^{A}\right) A_{d} & +\left(1+r_{f}^{A}\right) \cdot e_{1} A_{f}-\left(1+r_{d}^{L}\right) L_{d} \\
& -\left(1+r_{f}^{L}\right) \cdot e_{1} L_{f}
\end{aligned}
$$

Where $r_{d}^{A}$ and $r_{d}^{L}$ are interest rates for domestic asset and liabilities, while $r_{f}^{A}$ and $r_{f}^{L}$ are interest rates for foreign asset and liabilities. 
Suppose $\delta_{d}=r_{d}^{A}-r_{d}^{L}$ and $\delta_{f}=r_{f}^{A}-r_{f}^{L}$, then

$$
\begin{gathered}
W_{1}=\left(1+r_{d}^{A}\right)\left(A_{d}-L_{d}\right)+\left(1+r_{f}^{L}\right) \cdot e_{1}\left(A_{f}-L_{f}\right) \\
+\delta_{d} A_{d}+\delta_{f} e_{1} A_{f} \\
=\left(1+r_{d}^{L}\right)\left(A_{d}-L_{d}\right)+\left(1+r_{d}^{L}\right) e_{0}\left(A_{f}-L_{f}\right) \\
-\left(1+r_{d}^{L}\right) e_{0}(A-L) \\
+\left(1+r_{f}^{L}\right) \cdot e_{1}\left(A_{f}-L_{f}\right)+\delta_{d} A_{d}+\delta_{f} e_{1} A_{f} \\
=\left(1+r_{d}^{L}\right) W_{0}-\left(1+r_{d}^{L}\right) e_{0}\left(A_{f}-L_{f}\right) \\
+\left(1+r_{f}^{L}\right) e_{f}\left(A_{f}-L_{f}\right)+\delta_{d} L A_{d} \\
+\delta_{f} e_{1} A_{f} \\
=\left(1+r_{d}^{L}\right) W_{0}+\left[\left(1+r_{f}^{L}\right) e_{1}-\left(1+r_{d}^{L}\right) e_{0}\right]\left(A_{f}\right. \\
\left.-L_{f}\right)-\delta_{d} A_{d}+\delta_{f} e_{1} A_{f}
\end{gathered}
$$

Based on Equation (5), we can make an empiric model to predict the equity of company $i$ in year $t$ as

$$
\begin{aligned}
& W_{i, t}=\alpha_{0}+\alpha_{1}[\left.\left(A_{f}-L_{f}\right)_{i, t-1} \cdot \Delta e_{t}\right] \\
&+\alpha_{2}\left(A_{f}-L_{f}\right)_{i, t-1} \\
&+\alpha_{3} \Delta e_{t}+\alpha_{4} L_{i, t-1}^{d}+\alpha_{5} r_{t}
\end{aligned}
$$

If net foreign asset or NFA is defined as $\left(A_{f}-L_{f}\right)$, then

$$
\begin{array}{r}
W_{i, t}=\alpha_{1}\left[(N F A)_{i, t-1} \cdot \Delta e_{t}\right]+\alpha_{2}(N F A)_{i, t-1} \\
+\alpha_{3} \Delta e_{t}+\alpha_{4} L_{i, t-1}^{d}+\alpha_{5} r_{t}
\end{array}
$$

where

$E Q_{i, t}=$ equity to asset ratio

$\Delta e_{t}=$ Rupiah exchange rate (to USD)

$N F A_{i, t-1}=$ NFA to asset ratio

$L_{i, t-1}^{d}=$ domestic liabilities to asset ratio

$r=$ credit interest rate

In other words, a firm's equity is determined by these variables: its NFA in the previous year, exchange rate fluctuation, amount of domestic debt in the previous year, credit interest rate, and the interaction between NFA and exchange rate. We would like to find the coefficients of those variables to measure the impacts of each factors towards the firm's equity.

To estimate the values of $\alpha_{0}, \alpha_{1}, \alpha_{2}, \alpha_{3}, \alpha_{4}$, and $\alpha_{5}$, this study employs Support Vector Regression. It was founded by Vapnik (1998) [8] and used to address target variables with real values. In contrast to the squared loss function in ordinary least squares (OLS) regression, $\epsilon$ Support Vector Regression ( $\epsilon$-SVR) uses $\epsilon$-insensitive loss function, in which errors smaller than $\epsilon$ will be omitted. It has the form [9]

$$
|y-f(x)|_{\epsilon}:=\max \{0,|y-f(x)|-\epsilon\}
$$

The mathematical model to SVR is [10]

$$
y(x)=\boldsymbol{w}^{T} \phi(x)+b
$$

where $w$ denotes weight vector, $x$ denotes input vector, $\phi(x)$ is a function that transforms data into feature space, and $b$ is a bias constant.

We need to find $w$ (weight) and $b$ (bias) that minimizes [10]

$$
E(\boldsymbol{w}, b)=C \sum_{n=1}^{N} E_{\varepsilon}\left(y\left(x_{n}\right)-t_{n}\right)+\frac{1}{2}\|\boldsymbol{w}\|^{2}
$$

After we found $w, b$, and all the coefficients in Equation (7), we can predict firm's equities using the equation. To evaluate the accuracy of this method, we compare the firms' equity prediction in 2017 to their actual equity in the same year, and then find the RMSE (Root Mean Squared Error), where [11]

$$
R M S E=\left(\frac{1}{N} \sum_{i=1}^{n}\left(y_{i}-\widehat{y}_{l}\right)^{2}\right)^{\frac{1}{2}}
$$

\section{DATA}

This study uses data from following sources:

TABLE I: Data Source

\begin{tabular}{|c|c|}
\hline Data & Source \\
\hline $\begin{array}{c}\text { Financial Statements from 189 } \\
\text { nonfinancial firms that went public } \\
\text { on IDX (Indonesia Stock Exchange), } \\
\text { from 2011 to 2017. }\end{array}$ & $\begin{array}{c}\text { Indonesia Stock } \\
\text { Exchange Website }\end{array}$ \\
\hline $\begin{array}{c}\text { Indonesia External Debt Statistics } \\
\text { Exchange Rate }\end{array}$ & $\begin{array}{c}\text { Indonesian Ministry of } \\
\text { Finance }\end{array}$ \\
\hline & $\begin{array}{c}\text { Central Bank of } \\
\text { Indonesia }\end{array}$ \\
\hline
\end{tabular}

\section{RESULTS}

In implementing SVR, there are parameters besides $w$ (weight) and $b$ (bias) which values need to be determined before the $\mathrm{w}$ and $\mathrm{b}$ value could be found. These parameters are called hyperparameters. Different combination of hyperparameter values will result to different model performances. To obtain the best SVR model, these parameters should be tuned. [7]

In this study, we use grid search to tune the hyperparameters. We obtained the best model as such:

TABLE II: Optimum Hyperparameters

\begin{tabular}{|c|c|}
\hline Parameter & Value \\
\hline Kernel Function & Gaussian \\
\hline$C$ & 13.615 \\
\hline$\varepsilon$ & 0.05 \\
\hline$\gamma$ & 6.148 \\
\hline
\end{tabular}

From the best model, we obtained the weight and bias as such: 
TABLE III: Coefficients of the Optimum Model

\begin{tabular}{|c|c|c|}
\hline Variable & Coefficient & Sign \\
\hline $\begin{array}{c}\text { Interaction between NFA and } \\
\text { difference in exchange rate } \\
\left(\mathrm{NFA} \times \Delta \mathrm{e}_{\mathrm{t}}\right)\end{array}$ & 0,66410 & + \\
\hline NFA (Net Foreign Asset) & 0,85295 & + \\
\hline $\begin{array}{c}\text { Difference in exchange rate } \\
\left(\Delta \mathrm{e}_{\mathrm{t}}\right)\end{array}$ & 0,02152 & + \\
\hline Domestic liability ratio $\left(\mathrm{L}_{\mathrm{d}}\right)$ & $-0,85672$ & - \\
\hline Credit interest rate $(r)$ & $-0,02157$ & - \\
\hline Bias & 0.87295 & + \\
\hline
\end{tabular}

From Table 3, we observe that interaction between NFA and $\Delta e_{t}$ has positive coefficient. This indicates positive linear relationship between the interaction of two variables and the firm's equity. This means that if the observed company increases its NFA to asset ratio and the observed nation's exchange rate appreciates, the firm's equity would most likely increase as well. On the other hand, if the firm's NFA decrease and exchange rate depreciates, their equity would decrease too. This implies that the balance-sheet effect is more dominant in Indonesian corporations.

The NFA variable has positive coefficient, which means the more asset in foreign currencies a company owns, the more its equity will increase. Reversely, the more debt a company has in foreign currencies, the more its equity would decrease in the following year.

Difference in exchange rates also has positive coefficient, which indicates positive linear relationship between exchange rates and equity. This means when the currency the firm operates in experiences appreciation, the firm's equity will increase, while reversely, if the exchange rate depreciates, firm equity will also decrease.

Domestic liability has negative coefficient, which indicates negative linear relationship between domestic liability and equity. The more liability a corporation has in domestic currency will cause further decrease to its equity in the following year, and vice versa.

Credit interest rate also has negative coefficient which indicates negative linear relationship between credit interest rate and equity. This means the higher credit interest rate would cause further decrease in a firm's equity, and vice versa.

We could also find NFA threshold, which is the limit of minimum NFA to asset ratio such that a firm's equity to asset ratio would not decrease when depreciation occurs. NFA ratio threshold is denoted by NFA*, and we obtain it by finding the first partial derivative of Equation (7) to difference in exchange rate [2]:

$$
\frac{\partial W}{\partial \Delta e}=\alpha_{1}\left[(N F A)_{i, t-1}\right]+\alpha_{3}
$$

$\mathrm{NFA}^{*}$ would be the value of NFA ratio such that [2]:

$$
\alpha_{1}\left[(N F A)_{i, t-1}^{*}\right]+\alpha_{3}=0
$$

In this study, the NFA threshold is $-3.03 \%$, which means if a firm has more than $3.03 \%$ debt in foreign currency relative to its asset, the firm would most likely experience decrease in its equity when depreciation happens. On the other hand, if the firm has less than $3.03 \%$ debt, it would gain profit such that its equity will increase while depreciation happens.

To find the accuracy of this model, we compare the prediction made from this model with the actual equities of observed firms in year 2017 and calculate the RMSE. The RMSE from this optimized SVR model is $9.55 \%$, which is smaller than the RMSE obtained from OLS panel data regression model trained with the same dataset (11.68\%). The smaller RMSE value indicates the model obtained from SVR gave prediction with smaller error and hence, better accuracy.

\section{CONCLUSION}

From this study, we conclude that support vector regression could predict a firm's equity with better accuracy compared to the conventionally used ordinary least squares (OLS) panel regression method. Results showed that balance-sheet effect is more dominant than competitiveness effect in Indonesian corporations, and the Indonesian corporations have $3.03 \%$ of NFA (net foreign asset) ratio threshold. Corporations should be careful in maintaining their debt to asset ratio so that they won't experience loss and decrease in equity when depreciation occurs.

\section{ACKNOWLEDGEMENT}

This research was financially supported by the Indonesian Ministry of Research and Higher Education , with a PDUPT2019 research grant scheme (ID number NKB-1621/UN2.R3.1/HKP05.00/2019).

The authors would like to express appreciation to all reviewers for the improvement of this article.

\section{REFERENCES}

[1] Kementerian Keuangan Republik Indonesia, Statistik Utang Luar Negeri Indonesia edisi Maret 2018, v.02

[2] Biro Riset Ekonomi Bank Indonesia, Analisa Perilaku Pembiayaan Asing dan Dampaknya Terhadap Ketahanan Perusahaan, Working Paper WP/12/2011 Bank Indonesia.

[3] J.A. Frenkel and A Razin, The Mundell-Fleming Model: A Ouarter Century Later. National Bureau of Economic Research, 1987. Working Paper no. 2321

[4] P Krugman, Balance Sheets, the Transfer Problem, and Financial Crises. (Springer: Dordrecht, 1999) pp 31-55

[5] P Kintandani and Z Rustam, Application of Support Vector Regression in Indonesian Stock Price Prediction with Feature Selection Using Particle Swarm Optimisation, Modelling and Simulation in Engineering 2019.

[6] Z. Rustam, D. F. Vibranti, and D. Widya, Predicting the direction of Indonesian stock price movement using support vector machines and fuzzy kernel C-means, Proceedings of 3rd International Symposium on Current Progress in Mathematics and Sciences, Bali, Indonesia, 2017

[7] Z. Rustam, Nurrimah, and R. Hidayat, Indonesia Composite Index Prediction using Fuzzy Support Vector Regression with Fisher Score Feature Selection, International Journal on Advanced Science, Engineering and Information Technology, vol 9, no 12019.

[8] V.C. Vapnik, Statistical Learning Theory: Adaptive and learning systems for signal processing, communications, and control (Wiley, 1998) 
[9] C.M. Bishop, Pattern Recognition and Machine Learning (UK: Springer, 2006)

[10] J. Smola and B. Scholkopf, A tutorial on support vector regression, Journal of Statistics and Computing, vol. 1, pp. 199-222, 2002.

[11] D.C. Montgomery, E.A. Peck and G.G. Vining, Introduction to Linear Regression Analysis (New Jersey: Wiley, 2012). 